\title{
INSTYTUCJONALIZACJA RUCHU POLSKIEGO NA UKRAINIE W LATACH 1988-1991
}

WSTĘP

W ciąż aktualny jest temat Polaków zamieszkałych na Ukrainie, choć od wielu lat prowadzone są badania ich dotyczace (historyczne, lingwistyczne, dotyczące oświaty czy kultury), a Polska uwzględnia obecność Polaków na Wschodzie w swej polityce zagranicznej (zob. np. Plan Współpracy z PoIonią i Polakami Za Granicą w 2012 roku') i wspiera finansowo działania na rzecz Polonii ukraińskiej (zarówno w Polsce, m.in. Stowarzyszenie „Wspólnota Polska”, Fundacja „Pomoc Polakom na Wschodzie” czy Fundacja "Semper Polonia”, jak i na Ukrainie - liczne organizacje polskie, tzw. „Domy Polskie”, amatorskie zespoły artystyczne, szkoły wyższe i podstawowe z nauką języka polskiego itp.).

Polacy na Ukrainie są elementem polityki zagranicznej Polski, stanowią segment społeczeństwa ukraińskiego, w oczywisty sposób najmocniej (mimo stałego zwiększenia się liczby Ukraińców mających kontakt z Polską poprzez prace zarobkowe) powiązanych z Polską. Znalazło to odbicie w Ustawie o Karcie Polaka, której posiadanie potwierdza przynależność do Narodu Polskiego.

Znany badacz ukraiński, prof. Oleg Kałakura, stwierdza, że „Незважаючи на те, що кількість поляків в Україні впродовж 1990-х років помітно зменшилася, вони і надалі посідають домінуюче місце серед іноетнічних груп нашої держави"2.

Doc. dr Sergiusz RUDNICKI jest pracownikiem Uniwersytetu Państwowego im. Iwana Franki w Żytomierzu na Ukrainie. sergiuszrudnicki@gmail.com

Plan Wspótpracy z Polonią i Polakami Za Granicą w 2012 roku, Warszawa 2012, s. 46. Калакура О.Я., Поляки в етнополітичних процесах на землях України у XX столітmі. - К.: Знання України, 2007, s. 418. 
Celem artykułu jest przedstawienie instytucjonalizacji ruchu polskiego na Ukrainie w latach 1988-1991. Wybrałem ramy czasowe nieprzypadkowo, ponieważ w lipcu 1988 roku zaczął się proces kształtowania instytucji politycznych reprezentujących interesy mniejszości polskiej w Ukraińskiej Socjalistycznej Republice Radzieckiej, a 19.10.1991 roku powstała pierwsza krajowa organizacja polska w niezależnym państwie ukraińskim - Związek Polaków Ukrainy. Formy, treść, przebieg i charakter instytucjonalizacji w decydującym stopniu spowodowały taki a nie inny charakter aktywności podmiotów pozarządowych działających na korzyść mniejszości polskiej na Ukrainie.

Należy zaznaczyć, że instytucjonalizacja jest rozumiana w moim artykule jako proces i wynik kształtowania się organizacji i norm prawno-politycznych, regulujących działalność tych organizacji. W tym artykule nie będę rozpatrywał powstawania norm prawnych umożliwiających powołanie polskich organizacji społecznych na Ukrainie, jak i innych podmiotów zaspokających potrzeby grupy polskiej na Ukrainie (parafii katolickich, zespołów folklorystycznych, placówek edukacyjnych różnego typu, w których uczy się języka polskiego itp.). Temat ten ze względu na swoją złożoność wymaga oddzielnego opracowania.

Chcę też podkreślić, że w odniesieniu do ruchu polskiego instytucjonalizacja może być rozumiana w ujęciu ścisłym (dotycząca polskich organizacji społecznych) i szerokim - jako instytucjonalizacja współczesnego Państwa Ukraińskiego, które jako instytut polityczny uwzględnia interesy swych obywateli pochodzenia polskiego. Będę rozpatrywał w artykule instytucjonalizację w ujęciu ścisłym, aczkolwiek należy pamiętać, że bez ukształtowania się niezależnego Państwa Ukraińskiego i odpowiedniej bazy prawnej nie można byłoby mówić o instytucjonalizacji Polonii ukraińskiej. Należy też w tym miejscu przypomnieć, że organizacja społeczna (organizacja pozarządowa, stowarzyszenie) może być traktowana zarówno jako instytucja (społeczna), tak i instytut polityczny, zwłaszcza, że wykonuje ona funkcje zarówno społeczne, jak i polityczne. W tym artykule będę traktował polskie organizacje społeczne (stowarzyszenia, organizacje pozarządowe) jako instytuty systemu politycznego i mówiąc o instytucjonalizacji ruchu polskiego na Ukrainie, będę mówił o procesie i wyniku kształtowania się organizacji społecznych jako jednego z segmentów systemu politycznego.

Wśród najważniejszych opracowań naukowych poświęconych tematowi polskich organizacji społecznych Polonii Ukraińskiej, które to organizacje w wielu teoriach polityki grupowej i społeczeństwa obywatelskiego są podstawowymi instytutami politycznymi reprezentującymi interesy grupowe, należy przede wszystkim wymienić monografię prof. Olega Kałakury "Поляки в етнополітичних процесах на землях України у XX” i prof. Larysy Łojko „Громадські організації етнічних меншин України: природа, легітимність, діяльність"4, szereg artykutów badaczy polskich i ukraińskich, m.in. prof. Janusza M. Kupczaka „Polskie Stowarzyszenie Kulturalno-Oświatowe na Ukrainie (stan z 1990 r.)"5 i "Sprawy Polaków na Ukrainie w świetle „Dziennika Kijowskiego" (1992-1998)”, Lidii Kościuk-Kulgawczyk „Społeczno-kulturalne życie w Kijowie w latach 90. XX wieku"7

\section{-.....}

Калакура О.Я., оp. cit., s. 508.

Лойко Л.І., Громадські організації етнічних меншин України: природа, легітимність, діяльність. - К.: Фоліант, 2005, s. 634.

5 Janusz M. Kupczak, Polskie Stowarzyszenie Kulturalno-Oświatowe na Ukrainie (stan z 1990 r.) [w:] Mniejszości polskie i Polonia w ZSSR, Wrocław-Warszawa-Kraków 1992, s. 251-261.

6 Janusz M. Kupczak, Sprawy Polaków na Ukrainie w świetle "Dziennika Kijowskiego" (1992-1998) [w:] Z badań nad wspótczesną problematyką Państw Europy Środkowej i Wschodniej, Wrocław 2000, s. 161-184.

7 Kościuk-Kulgawczyk L., Społeczno-kulturalne życie Polaków w Kijowie w latach 90. XX wieku, „Pamiętnik Kijowski", Kijów 2002, T. VI, Polacy w Kijowie, s. 301-319. 
i "Polskie organizacje społeczne należące do Związku Polaków na Ukrainie (ZPU)"8, Zofii Stawskiej "Stowarzyszenie Uczonych Polskich na Ukrainie"9.

Cenne ze względu na opis sytuacji stosunków polsko-ukraińskich i początków ruchu polskiego w Związku Radzieckim są artykuły Natalii Iszuninej „Роль громадських зв'язків в українсько-польських міждержавних взаєминах"10, Oksany Babak "Політичні відносини України та Польщі у 1980-2005 роках"11 і praca zbiorowa "Польский диалог. События в Польше глазами польских, советских, американских, английских, западнонемецких и французских журналистов"12. Szczegolnie ważnymi źródłami są wspomnienia pierwszego prezesa Związku Polaków Ukrainy, Stanisława Szałackiego, oraz inne materiały zamieszczone w pracy zbiorowej „Jak trudno być Polakiem!" ${ }^{13}$, wspomnienia Leszka Mazepy, pierwszego prezesa Towarzystwa Kultury Polskiej Ziemi Lwowskiej, wydrukowane w drugiej połowie 2008 roku w dwutygodniku „Kurier Galicyjski” 14, a także zbiór esejów byłego konsula RP w Kijowie w latach 1996-1999, Eugeniusza Jabłońskiego, pt. „Wzlot. Dokąd zmierzają Polscy na Ukrainie”15. Temat instytucjonalizacji interesów mniejszości polskiej we współczesnej Ukrainie jest mi bliski, poświęciłem mu kilka artykułów naukowych ${ }^{16}$, jestem redaktorem i jednym z autorów informatora „PoIonia Żytomierszczyzny", dotyczącego podmiotów polonijnych działających w obwodzie żytomierskim ${ }^{17}$. Oczywiście, wymienione przeze mnie źródła mają różną wartość poznawczą ze względu na subiektywizm i niekiedy błędne podawanie faktów (dotyczy to przede wszystkich wspomnień) lub nastawienie idelogiczne (dotyczy to prac wydanych w ZSRR lub napisanych później, ale pozostających pod wpływem radzieckiego schematu ukazywania stosunków polsko-radzieckich).

- •.・

8 Kościuk-Kulgawczyk L., Polskie organizacje społeczne należące do Związku Polaków na Ukrainie (ZPU)، [w:] Kultura i świadomość etniczna Polaków na Wschodzie. Tradycja i wspótczesność, Wrocław 2004, S. 345-351

9 Stawska Z., Stowarzyszenie Uczonych Polskich na Ukrainie, Kultura i świadomość etniczna Polaków na Wschodzie, [w:] Kultura i świadomość etniczna Polaków na Wschodzie. Tradycja i wspótczesność, Wrocław 2004,s. 353-356.

10 Ішуніна Н. Роль громадських зв'язків в українсько-польських міждержавних взаєминах, [w:] Polska i Ukraina po // wojnie światowej (red.). Włodzimierz Bonusiak, Rzeszów 1998, s. 27-40.

11 Бабак О., Політичні відносини України та Польщі у 1980-2005 роках [W:] Поляки на півдні України: Історія та сьогодення. У 2 Т. - Т.2. - Жешов; Київ, Миколаїв: Видавництво МДгУ ім. П. Могили, 2008, s. 108-151.

12 Брониславский Е., Вачнадзе Г. Польский диалог. События в Польше глазами польских, советских, американских, английских, западнонемецких и французских журналистов. - Тбилиси: „Гантлеба”, 1990,s. 640 .

13 „Jak trudno być Polakiem”: Як важко бути поляком” / Авт. Концепції Є. Шалацький. - К.: Головна спеціаліз. ред. літ. мовами нац. меншин України: Спілка поляків України, 1997, s. 336.

14 Mazepa L., Dwudziestolecie TKPZL [w:] Kurier Galicyjski. Niezależne pismo Polaków na Ukrainie. Założyciel i wydawca Mirostaw Rowicki. - nr 11 (63) - 17(69), 2008.

15 Jabłoński E., Wzlot. Dokąd zmierzają Polscy na Ukrainie, Warszawa 2004, s. 228.

16 Rudnicki S., Polskie Towarzystwo Naukowe w Żytomierzu [w:] Heureka. Problemy społecznego ruchu naukowego, Warszawa 2005, s. 187-207; Динаміка реєстрації польських національно-культурних товариств Житомирщини у 1989-2004. [w:] "Украініка полоніка", t. 2 - Київ-Житомир, 2005, s. 216-222; Polskie organizacje społeczne Żytomierszczyzny. Zarys problematyki badawczej. Historia powstawania organizacji, [w:] Diaspora. T. II. Polska tożsamość na emigracji. Pod redakcją Jacka Leońskiego i Leszka Wątróbskiego, Szczecin 2007, s. 241-250; Джерельна база дослідження польських національно-культурних товариств як умова аналізу функціонування інститутів громадянського суспільства, [w:] Політична наука в Україні: стан і перспективи: матеріали всеукраїнської наукової конференції (Львів, 10-11 травня 2007 року) / Укл. Поліщук М., Скочиляс Л., Угрин Л. - Львів, ЦПД, 2008, s. 95-101; Działalność naukowa i popularyzatorska polskich organizacji społecznych na Żytomierszczyźnie, [w:] II Kongres Polskich Towarzystw Naukowych na Obczyźnie. 4-7 września, Kraków 2010, s. 241-259.

17 Інформаційно-аналітичне видання «Полонія Житомирщини» / за ред. Рудницького С.В. Житомир 2007, s. 220 . 


\section{SYTUACJA MNIEJSZOŚCI POLSKIEJ W ZSRR I FORMY ŻYCIA SPOLECZNO-POLITYCZNEGO POLAKÓW}

Żeby przedstawić rozwój społeczno-polityczny Polaków na Ukrainie, należy przede wszystkim dokonać chociażby krótkiego przeglądu sytuacji mniejszości polskiej w ZSRR epoki tzw. breżniewskiego „rozwiniętego socjalizmu”.

Oficjalnie ZSRR było państwem wielonorodowościowym, rząd i partia deklarowały, że stosunkom pomiędzy narodowościami poświęcają dużo uwagi, przy czym postulowano, że problem współżycia narodowości jest w zasadzie rozwiązany. Radziecka polityka narodowościowa miała doprowadzić do wytworzenia się narodu radzieckiego, co wiązało się z unifikowaniem różnic pomiędzy narodowościami na korzyść kultury rosyjskiej. Mimo że w latach 80. XX wieku ZSRR był drugim po USA państwem pod względem liczebności mniejszości polskiej (1 mln 151 tys. Polaków $\left.{ }^{18}\right)$, możliwości realizacji swych interesów dla mniejszości polskiej były bardzo ograniczone.

Ze względu na totalitarny charakter państwa radzieckiego, w którym obowiązywała jedna ideologia i jedna partia polityczna, nie było pluralizmu politycznego i instytucji społeczeństwa obywatelskiego. Organizacje pozarządowe w ZSSR miały w myśl znanego ukraińskiego badacza Antoniny Kołodij wykonywać funcję pasów transmisyjnych, łączących aparat państwowo-polityczny z narodem, mobilizować masy do udziału w życiu społeczno-politycznym ZSRR. Wykonywały one także fukcje kamuflażowe, pokazując wpólnocie międzynarodowej, że w ZSRR istnieje życie społeczne ${ }^{19}$.

Niemniej jednak, istniały małe obszary, gdzie mogły być realizowane interesy obywateli, w tym narodowości polskiej, zamieszkałych w ZSRR. Polacy na Ukrainie Radzieckiej mieli możliwość częściowo realizować swe interesy narodowe poprzez:

1. udział w działalności towarzystw przyjaźni polsko-radzieckiej;

2. kontakty nieformalne poprzez sieć księgarni "Drużba” (księgarnie literatury w językach obcych), które istniały w centrach obwodowych, poprzez działy literatury w językach obcych w bibliotekach obwodowych, podtrzymujące poskość poprzez zakup odpowiednich książek;

3. kontakty nieformalne poprzez udział w nabożeństwach w nielicznych kościołach katolickich, działających po 1975 roku w mniej rygorystycznych warunkach, podtrzymywanie polskości poprzez słuchanie audycji I programu Polskiego Radia, a także telewizji polskiej w obszarach przygranicznych;

4. podtrzymywanie polskości poprzez czytanie prasy polskiej, prenumerowanej i kupowanej w kioskach i specjalistycznych sklepach "Sojuzpieczati".

W Związku Radzieckim od 1957 roku, a w PRL od 1944 roku działały towarzystwa przyjaźni polsko-radzieckiej. Mimo ścisłej kontroli partii i służb specjalnych w ramach wymiany delegacji, organizowanych przez te organizacje, nawiązywano kontakty nieformalne.

W drugiej połowie lat 80. w sieci księgarni „Drużba” , które istniały w centrach obwodowych, można było kupić polskie książki, podręczniki do nauki języka polskiego, słowniki polsko-rosyjskie. Wszystkie biblioteki obwodowe miały działy książek w językach obcych, w tym - polskim, i prowadziły prenumeratę gazet oraz czasopism polskich. I tak, w Żytomierzu wydział literatury w językach obcych miał 5 tys. egzemplarzy książek polskich,

18 Брониславский Е., Вачнадзе Г., ор. cit., s. 360

19 Колодій А., Становлення громадянського суспільства в Україні // «ї ». - 2001. - № 22. [w:] http://www. ji.lviv.ua/ n22texts/ kolodij.htm 
poza tym w kościele katedralnym Św. Zofii w Żytomierzu istniała, dzięki zakupom książek, biblioteka parafialna, która miała księgozbiór literatury religijnej i świeckiej.

Po II wojnie światowej część kościołów nie została ponownie (po zezwoleniu na funcjonowanie wydane przez okupacyjne władze niemieckie) zamknięta, dotyczyło to przede wszystkim kościołów w dużych miastach (np. w Kijowie), gdzie odprawiano nabożeństwa także w języku polskim. Placówki te poprzez nabożeństwa w językach angielskim, francuskim czy innych dla cudzoziemców z korpusu dyplomatycznego miały pokazać, że w ZSRR istnieje wolność sumienia. Po Konferencji w Helsinkach w 1975 roku zmiejszyło się prześladowanie wiernych; kontakt z polszczyzną (a w tym języku odbywały się nabożeństwa np. w trzech kościołach w obwodzie żytomierskim - w Żytomierzu, kościele we wsi Nowy Zawód pow. czerwonoarmiejskiego i wsi Pokostówka) miały pewne grupy wiernych - byli to przede wszystkim emeryci, ale także robotnicy, chociaż już w ich wypadku groziły restrykcje ze strony władz, o młodzieży, dzieciach i inteligencji nie wspominając.

Jest paradoksem, że prasa polska, która poprzez charakter polskiej odmiany socjalizmu miała wiele treści niezupełnie odpowiadających odmianie socjalizmu radzieckiego, była szeroko dostępna w kioskach, w prenumerecie i w specjalistycznych sklepach radzieckiego odpowiednika „Ruchu”. Na Ukrainę według danych badaczki ukraińskiej Oksany Babak docierało ponad 30 tys. egzemplarzy gazet i czasopism, z których 20 tys. sprzedawano, dotyczyło to takich pozycji jak „Polityka”, „Kultura”, Życie Literackie”, „Życie Warszawy”, „Sztandar Młodych”, „Panorama”, „Żołnierz Wolności”20.

Należy wspomnieć, że ważne znaczenie miały audycje I programu Polskiego Radia (bardzo popularne programy muzyczne, szczególnie „Muzyka Nocą"), poza tym warto pamiętać, że sytuacja na Zachodniej Ukrainie była nieco inna, ponieważ we Lwowie istniały dwie polskie szkoły i był dostęp do telewizji polskiej.

Rok 1980 przyniósł pewne zmiany w sytuacji prasy polskiej i współpracy polsko-radzieckiej. W związku z aktywnością "Solidarności” zaniechano sprowadzania prasy polskiej do URRS, służby specjalne kontrolowały jej nadejście poprzez korespondencję prywatną, a także prenumeratę dla uczelni i instytucji naukowych. Z drugiej strony, wzmocnily się kontakty obywateli ukraińskich, w tym pochodzenia polskiego, z Polakami z Polski, ponieważ zacieśniła się współpraca polsko-radziecka. Żeby nie dopuścić do wzmocnienia pozycji „Solidarności” ani w Polsce, ani poza jej granicami, CK KPZR uchwalił decyzje "O planie współpracy KPZR z partiami komunistycznymi i robotniczymi na lata 1982-1983". Uchwałą z 23.02.1982 roku KC PZPR zobowiązano Wyższą Szkołę Partyjną przy KC KPU, by organizowała ona szkolenia sekretarzy Komitetów Wojewódzkich PZPR, wicewojewodów, redaktorów gazet wojewódzkich. Centrale Obwodowe Związków Zawodowych organizowały szkolenia działaczy związkowych z Polski, przyjmowano na odpoczynek do obozów pionierskich harcerzy ${ }^{21}$.

Jest oczywiste, że ze względu na charakter państwa radzieckiego możliwość realizowania potrzeb religijnych, kulturowych, edukacyjnych, nie mówiąc już o politycznych, mniejszości polskiej na Ukrainie była znikoma, niemniej w wielu przypadkach życie polskie odradzało się dzięki osobom, które miały kontakt z polskością poprzez udział w tych czy innych formach życia polskiego w Związku Radzieckim. Oprócz tego, początki instytucjonalizowanych form życia polonijnego mają źródło właśnie w instytucjach radzieckich.

20 Бабак O., op. cit., s. 112

21 Ibidem, s. 110. 
Sytuacja zaczyna się zmieniać z początkiem pieriestrojki, ogłoszonej przez Michaiła Gorbaczowa w 1985 roku. Po spotkaniu Gorbaczowa z Wojciechem Jaruzelskim 21 kwietnia 1987 roku podpisano Deklarację o współpracy polsko-radzieckiej, tekst której wydrukowano w „Trybunie Ludu" 1 maja 1987 roku. Przewidywała ona współpracę w sferze ideologii, kultury i nauki22.

W referacie na XIX Konferencji KPZR w czerwcu 1988 roku Gorbaczow po raz pierwszy powiedział o prawach i wolnościach jednostki, o rozwoju narodowych języków i kultur, oczywiście, w kontekście „przewagi socjalizmu” ${ }^{23}$. Stało się to dla wszystkich narodowości zamieszkałych w Związku Radzieckim sygnałem do mobilizacji narodowej, do rozwoju tożsamości etnicznej i politycznej, konsolidacji sił dla odrodzenia etnicznego i odpowiednio - instytucjonalizacji swych interesów w państwie radzieckim. Było to sygnałem także dla Polaków na Ukrainie, aczkolwiek różne osoby podają różne daty początku instytucjonalizacji grupy polskiej.

Są różne opinie dotyczące czasu powstawania polskich organizacji społecznych. I tak, według wspomnień konsula generalnego RP w Kijowie w latach 1987-1992, Ryszarda Polkowskiego, możliwość powołania sekcji polskiej przy Towarzystwie Przyjaźni i Łączności z Zagranicą powstała w 1989 roku²4. Według Jerzego Szałackiego, syna pierwszego prezeza Związku Polaków Ukrainy, w latach 1986-1987 jego ojciec otrzymał z KG RP w Kijowie zaproszenie na spotkanie z pierwszym niekomunistycznym premierem Polski Tadeuszem Mazowieckim w Moskwie ${ }^{25}$, co jakoby dało początek instytucjonalizacji ruchu polskiego (wersja ta jest błędna, ponieważ wówczas T. Mazowiecki nie był premierem RP). Bardziej wiarygodna wydaje się informacja mówiąca o tym, że wkrótce po ogłoszeniu przez Gorbaczowa zmian w dziedzinie polityki narodowościowej, w lipcu 1988 roku, odbyto się pierwsze posiedzenie tzw. „polskiej sekcji” przy Towarzystwie Przyjaźni i Łączności Kulturalnej z Zagranicą - w czerwcu albo 5 lipca. Wiadomo, że kierownik Towarzystwa konsultował kandydaturę na kierownika sekcji z Konsulem Generalnym RP w Kijowie i ten wskazał na Stanisława Szałackiego, emerytowanego wojskowego, który w latach 80. był w Polsce na zaproszenie Towarzystwa Przyjaźni Polsko-Radzieckiej. Na pierwszym posiedzeniu „sekcji” byli Polacy z Żytomierza, Lwowa, Winnicy i Chmielnickiego - pracownicy uczelni wyższych, członkowie Oddziałów Obwodowych Towarzystwa „Przyjaźń", nauczyciele. Drugie posiedzenie odbyło się 5 sierpnia 1988 roku².

W okresie pomiędzy czerwcem/lipcem a październikiem 1988 roku trwały prace nad poszerzeniem geografii oddziałów organizacji, właśnie wtedy, już na początkowym etapie instytucjonalizacji ruchu polskiego, dał się we znaki odwieczny ukraiński problem dwóch Ukrain - wschodniej (naddnieprzańskiej, rosyjskiej) i zachodniej (polskiej i austro-węgierskiej), z centrum we Lwów

Inicjatorem utworzenia organizacji polskiej we Lwowie był prof. Leszek Mazepa, uczeń przedwojennej szkoły polskiej, muzykolog. Pomagali mu w tym Adolf Wisłowski, lekarz i nauczyciel, polonista Adam Kokodyński. Organizacja ta mogła pełnić funkcje ośrodka stowarzyszenia krajowego w Kijowie, w okresie pomiędzy lipcem i październikiem 1988 roku odbyło się spotkanie L. Mazepy ze Stanisławem Szałackim i Anato-

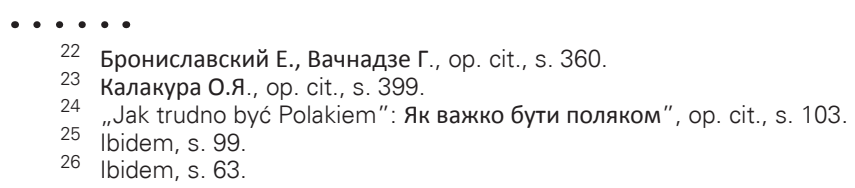


lem Romejko w Kijowie, a L. Mazepa napisał, że uderzył go fakt, iż pomiędzy sobą rozmawiają oni w języku rosyjskim: "Jakżeż to - dwaj prezesi Polskiego Stowarzyszenia Kulturalno-Oświatowego rozmawiają ze sobą w obcym języku?!". To spowodowało, że do utworzenia organizacji we Lwowie, jako oddziału Polskiego Stowarzyszenia Kulturalno-Oświatowego, nie doszło. Wybrani na posiedzeniu 5 października 1988 roku do Zarządu PSKO Iwowianie Lucyna Kowalska i Władysław Łokietko zrezygnowali z pracy w stowarzyszeniu na rzecz pracy w TKPZL.

Warto więc mówić o dalszym rozwoju wydarzeń z osobna. Jeśli chodzi o PSKO, to 5 października 1988 roku, na trzecim posiedzeniu, podjęto decyzję o przekształceniu Sekcji w niezależne Polskie Stowarzyszenie Kulturalno-Oświatowe ${ }^{27}$. Liczyło ono wtedy 30 osób. W opracowaniu statutu organizacji uwzględniono doświadczenie Polaków z Litwy. Od października 1988 do marca 1989 roku odbywały się zebrania założycielskie i tworzenie ośrodków w obwodach oraz odpowiednio - w powiatach, od marca 1989 do maja 1990 roku (po zarejestrowaniu statutu 13.03.1989 roku) - uroczyste zebrania w obwodach i proces kształtowania się struktur obwodowych i powiatowych zgodnie z zarejestrowanym w Ministerstwie Sprawiedliwości statutem, m.in. w Żytomierzu, Chmielnickim, Winnicy i innych miejscowościach.

Należy wspomnieć, że utworzenie ośrodków obwodowych i powiatowych (które odbywało się w dwóch etapach - pierwszy to zebranie założycieli, którzy deklarują, że chcą utworzyć organizację i wysyłają wyciąg z protokołu do organizacji krajowej, i drugi, kiedy po rejestracji statutu organizacji w Ministerstwie Sprawiedliwości odbywa się zebranie założycielskie na podstawie statutu organizacji krajowej) odbywało się za zgodą władz partyjnych - i tak, zebranie oddziału żytomierskiego, któremu decyzją Zarządu Gtównego PSKO z dnia 25 lutego 1989 roku nadano imię Jarosława Dąbrowskiego, odbyło się 18 marca 1989 roku, z okazji 118. rocznicy komuny paryskiej, za zgodą Obwodowego Wydziału Partii w Domu Oświaty Politycznej z udziałem konsula RP w Kijowie R. Polkowskiego, S. Szałackiego i władz partyjnych, a gości witała orkiestra dęta szkoły wojskowej28.

W dniu 13 maja 1990 roku odbył się I Kongres ZPU, który przyjął stosowną odezwę do Polaków Ukrainy i władz państwowych, uchwalił Statut organizacji, wybrał Zarząd Główny w składzie 23 osób $^{29}$. Znamienne, że w rezolucji uchwalonej na Zjeździe Polacy podzielali pragnienia niepodległościowe Narodu Ukraińskiego i proklamowali wzmocnienie gospodarczej i politycznej niezależności Ukrainy. Przypomnę, że odbywało się to przed uchwaleniem Deklaracji o Suwerenności Państwowej Ukrainy z 16 lipca 1990 roku. Stowarzyszenie liczyło w maju 1990 roku 5 tys. członków i miało 5 oddziałów obwodowych - w Kijowie, Żytomierzu, Winnicy, Chmielnickim i Tarnopolu.

Jeśli chodzi o Towarzystwo Kultury Polskiej Ziemi Lwowskiej, zebranie założycielskie tej organizacji odbyło się 3 grudnia 1988 roku, uchwalono Statut organizacji, wybrano prezesa (Leszek Mazepa) i Zarząd (Adam Kokodyński, Władysław Łokietko - były członek Zarządu PSKO, Adolf Wisłowski, Bożena Sokołowska i Zofia Szelechta).

Należy wspomnieć, że Ukraińcy po 1988 roku też rozpoczęli proces mobilizacji etnicznej. Idea powołania Ludowego Ruchu Ukrainy „za perebudowę" powstała w końcu 1988 roku w środowisku pisarzy, naukowców, dysydentów z lat 60. W dniu 16 lutego 1989 roku gazeta „Literaturna Ukraina” wydrukowała projekt powołania organizacji i mimo przeszkód ze strony struktur partyjnych i służb specjalnych we wrześniu 1989 roku odbył

27 Ibidem, s. 145.

28 Ibidem, s. 115-117.

29 Ibidem, s. 158. 
się jej zjazd założycielski. 14\% delegatów stanowili przedstawiciele mniejszości narodowych Ukrainy, w tym Polacy, a udział w Zjeździe wzięła liczna delegacja "Solidarności”, m.in. Adam Michnik, Bogdan Borusewicz, Bogumiła Bedychowska, Włodzimierz Mokry i inni. Uchwalono statut Ruchu i oddzielną deklarację dotyczącą praw mniejszości narodowych Ukrainy. W lutym 1990 roku utworzono radę narodowości Ruchu, która miała stać się centrum koordynującym działalność organizacji mniejszości narodowych ${ }^{30}$.

W dniu 24 sierpnia 1991 roku Ukraina zdobyła niezależność. W związku z tym podjęto decyzję o przeprowadzeniu II Kongresu ZPU, który odbył się 19 października 1991 roku. Wówczas Związek liczył około 10 tys. członków i miał oddziały obwodowe w Kijowie, Żytomierzu, Chmielnickim, Ługańsku, Charkowie i Odessie (20 oddziałów wraz z powiatowymi i innymi miejskimi).

W słowie wstępnym S. Szałacki przywitał Naród Ukraiński w związku ze zdobyciem niezależności, w takim duchu też uchwalono rezolucję Zjazdu. Zachęcano Polaków do głosowania na niezależną Ukrainą w grudniowym referendum. Podjęto decyzję o przekształceniu PSKO USRR w Związek Polaków Ukrainy, uchwalono odpowiednie zmiany do Statutu, który zarejestrowano w Ministerstwie Sprawiedliwości Ukrainy 16 lutego 1992 roku i przerejestrowano 30 stycznia 1993 roku. Ponownie wybrano S. Szałackiego na prezesa organizacji, a do składu Zarządu Głównego wybrano 31 osób.

Początki Związku Polaków Ukrainy okazały się też początkami osłabienia jego pozycji w skali Ukrainy. Pośpiech przy zwołaniu Kongresu, który miał odbyć się koniecznie przed referendum doprowadził do tego, że delegatów na zjazd wybierano niezupełnie demokratycznie. Na ten czas w ramach organizacji już działała silna opozycja podolska i kijowska przeciwko S. Szałackiemu, w terenie zaczeły powstawać organizacje spoza ZPU (np. w Żytomierzu). Dosłownie kilka dni po Kongresie - w dniu 26 października 1991 roku we Lwowie zebrało się grono organizacji, które postanowiły powołać krajową federację organizacji polskich. Na kursokonferencji, zorganizowanej przez Stowarzyszenie „Wspólnota Polska” i Fundację „Edukacja dla demokracji” w dniach 11-15 stycznia 1992 roku w Satanowie na Podolu postanowiono utworzyć Federację Organizacji Polskich na Ukrainie, której zebranie założycielskie odbyło się 25 stycznia 1992 roku we Lwowie z udziałem 73 delegatów z 18 miejscowości ${ }^{31}$. ZPU proponowano wejście do Federacji, ale uwagi ZPU do statutu Federacji odrzucano, więc do wejścia ZPU do Federecji nie doszło i ostatecznie od tego czasu na Ukrainie działają dwie krajowe, poniekąd rywalizujące między sobą, organizacje polskie - ZPU i FOPU.

S. Szałacki odszedł od aktywnej działalności w 1992 roku i przekazał sprawy członkowi Zarządu S. Kosteckiemu, chociaż do swej śmierci (zm. 6 stycznia 1996 roku) pomagał w działalności Związku. Jeśli chodzi o Leszka Mazepę, to odszedł on od działalności w TKPZL w 1990 roku, po zebraniu, na którym zarzucono mu wypowiedzi na konferencji „Kraj i emigracja”, ponoć nieuzgodnione z członkami organizacji. L. Mazepa zrezygnował z pełnienia obowiązków prezesa 20 stycznia 1991 roku. Są pewne wątki „polskie” w tych wydarzeniach, ponieważ Stowarzyszenie „Wspólnota Polska” przez dłuższy czas stawiało na Federację, rezygnując z finansowania ZPU, a zdaniem L. Mazepy, w tworzeniu opozycji przeciwko niemu zaangażował się ówczesny konsul RP we Lwowie.

Według spisu ludności z 2001 roku na Ukrainie mieszka 144,1 tys. osób, które zadeklarowały się jako Polacy, działa (według danych portalu internetowego Stowarzyszenia „Wspólnota Polska”) 635 podmiotów polonijnych. Na Żytomierszczyźnie, gdzie mieszka

30 Калакура О.Я., ор. cit., s. 393-394

31 Jabłoński E., op. cit., s. 23-24. 
według danych oficjalnych 49 tys. osób narodowości według danych informatora „Polonia Żytomierszczyzny" w 2007 roku działało 36 polskich organizacji społecznych, 18 zespołów amatorskich i 118 parafii rzymskokatolickich ${ }^{32}$.

PODSUMOWANIE

Możliwości zaspokajania potrzeb religijnych, kulturowych, edukacyjnych, nie mówiąc już o politycznych, mniejszości polskiej na Ukrainie, ze względu na charakter państwa radzieckiego, były mocno organiczone. Instytucjonalizowane formy życia społecznego Polaków znajdowały się pod kontrolą wydziałów ideologii odpowiednich komitetów KPZR i służb specjalnych, udział w towarzystwach przyjaźni polsko-radzieckiej był ściśle reglamentowany. Mimo to w wielu przypadkach odrodzenie życia polskiego odbywało się dzięki osobom, które miały kontakt z polskością poprzez udział w tych czy innych formach życia polskiego w Związku Radzickim.

Proces instytucjonalizacji polskich organizacji społecznych nosił odgórny charakter nie były to organizacje sterowane ani stwarzane dekretami, niemniej, zezwolenie na ich utworzenie uzyskiwano w wydziałach ideologicznych odpowiednich komitetów partyjnych (także jeszcze w marcu 1989 roku). Organizacje te (przynajmniej jeśli chodzi o Naddnieprzańską Ukrainę) w początkowym okresie swej instytucjonalizacji od lata do końca 1988 roku tworzyły się w kierunku od centrum do peryferii (tak jak w nakazowym modelu systemu politycznego, właściwym dla państwa totalitarnego) i opierały się na już istniejących „starych" organizacjach, czyli Towarzystwie Łączności i Związków Kulturalnych z Zagranicą.

Ponieważ Zachodnia Ukraina ma inną kulturę polityczną, utworzenie organizacji polskich przebiegało tam inaczej - były to organizacje tworzone oddolnie, co więcej - niezwiązane z organizacjami w Centralnej Ukrainie w sposób instytucjonalny. W taki sposób od razu ukształtowały się dwa ośrodki społecznego życia polskiego na Ukrainie - kijowski i lwowski.

Mobilizacja etniczna mniejszości polskiej na Ukrainie odbyła się szybciej niż samych Ukraińców, może ze względu na to, że w przypadku Ukraińców miała ona także charakter polityczny, co w końcu doprowadziło do uzyskania suwerenności dla narodu ukraińskiego. Początkowy etap mobilizacji etnicznej Polaków, w ramach tzw. Ruchu, nie stał się podstawą dla utworzenia polskich organizacji społecznych. Władze partyjne okazały się szybsze - utworzenie PSKO odbyło się o wiele wcześniej niż samego Ruchu.

Pierwsza polska organizacja społeczna - Polskie Stowarzyszenie Kulturalno-Oświatowe - była prekursorem form aktywności powielanych później przez inne organizacje społeczne - takich form, jak kursy języka polskiego, nauka języka polskiego w szkołach, utworzenie zespołów polonijnych, organizacja festiwali i konkursów, olimpiad języka polskiego, wyjazdów do Polski na odpoczynek w lecie itp. Niektóre formy działalności pozostały, inne jednak dość szybko zostały przejęte przez inne podmioty - stowarzyszenia (np. nauczycieli polonistów), państwo ukraińskie (np. nauka w szkolach, TV i radio) i polskie (m.in. rekrutacja na studia wyższe do Polski).

32 Інформаційно-аналітичне видання «Полонія Житомирщини», op. cit. 


\section{THE INSTITUTIONALIZATION OF THE POLISH MOVEMENT IN UKRAINE, 1988-1991}

\section{Summary}

For a long time the Polish minority in Ukraine was unable to fulfill its religious, cultural, educational, and political needs because of the Soviet communist regime. All institutions were controlled by the Communist Party and state security organs. Nevertheless, the process of the rebirth of Polish institutions and organizations began in 1989 via the former channels of the communist apparatus which was prepared to allow limited concessions. Thus the process was from above and not from below, from the center to the periphery, according to the former command political system. It relied on former organisations, mostly Towarzystwo Łączności i Związków Kulturalnych z Zagranicą.

However, the ethnic mobilization of the Polish minority in Ukraine proceeded faster than the equivalent process embracing the Ukrainians themselves, who fought also for sovereignty for the nation. The article describes in detail the phases of forming the Polish organizations for which Polskie Stowarzyszenie Kulturalno-Oświatowe was a precursor, and its forms of activity, later imitated by other social organizations, such as Polish language courses, festivals and competitions, folk dancing, travel to Poland.

Key words: institutionalization, Polish movement, Ukraine 